\title{
Ameliorative effects of coconut oil on the ovaries of refinery effluent intoxicated Norwegian rats
}

\author{
Ekaye S. ${ }^{1}$, Uwagie-Ero E. A. ${ }^{2} *$ and Aghayedo C. O. ${ }^{3}$ \\ ${ }^{1,3}$ Department of Animal and Environmental Biology, University of Benin, Benin City, Edo State, Nigeria \\ ${ }^{2}$ Department of Veterinary Surgery, University of Benin, Benin City, Edo State, Nigeria \\ Corresponding Author: *edwin.uwagie-ero@uniben.edu
}

\begin{abstract}
The study was conducted to determine the possible ameliorative activity of coconut oil on the toxic effects of untreated refinery effluents on the ovaries of Norwegian rats. Three experimental groups of 10 rats each were used for the study; all animals had feed and water ad libitum. Group 1 was untreated and served as the control group, Group 2 was treated with $2 \mathrm{ml}$ of untreated refinery effluent daily $P O$ and group 3 was treated with $2 \mathrm{ml}$ of untreated refinery effluent and $2 \mathrm{ml}$ of coconut oil daily $P O$ for 9 weeks. Every 3 weeks 2 rats in each group were euthanized with chloroform and ovarian tissues were surgically harvested; tissue concentration of heavy metals was assayed and histology was carried out. Treatment was discontinued at nine weeks and rats in group 2 and 3 were designated groups 4 and 5; allowed a 21 days resting period after which they were euthanized, ovaries surgically harvested and assayed as well. Results indicate that changes in ovarian tissue concentration of Chromium and Lead in the treated groups were of statistical significance $(P \leq 0.05)$ compared to control. Results also showed that rats treated with coconut oil as abatement had normal histological architecture. Coconut oil had ameliorative effects on the ovary of rats intoxicated with refinery effluent and the ovaries returned to normal activities within 21 days post exposure.
\end{abstract}

Keywords: Coconot oil, Refinery Effluents, Ovary, Toxicity, Amelioration

\subsection{Introduction}

Coconut oil, a potent natural yeast fighter, contains three medium chain fatty acids, i.e., lauric acid (50-53\%), caprylic acid and capric acid, all of which have antifungal effect against Candida spp and other fungi. Coconut oil has been confirmed to possess antimicrobial, antiviral and antiprotozoal activities (Isaacs et al., 1995; Thormar, 1996; Enig, 2000).

Increased human and industrial activities have led to increased pollution of man's environment and water bodies. Industrial waste which includes heavy metals and toxic chemicals are increasingly contaminating the environment. Deposits of metals and chemicals from industrial effluents can be found in the food and water consumed by both man and animals most especially when they are not properly treated before disposal.

Crude refinery effluents usually contain a variety of heavy metals such as chromium and lead; decreases in body weight gain have been reported in mice exposed to chromium and lead (Calvero et al., 1989; Campbell et al., 1989; Kanojia et al., 1998; Isselhard and Kushe, 1998; Giridharan, 2000; Ihedioha et al., 2004).

The Norwegian rat (Rattus norvegicus) is preferably used for toxicity assessment as they are the closest available bridge to the actual assessment in human population (Tawari et al., 2002). For a clearer insight into the histopathological effects of exposure to untreated refinery effluents an assessment on the toxicity response of Norwegian rat (Rattus novergicus) exposed to untreated refinery effluents with possible amelioration of these effects with the use of coconut oil was carried 
out. The specific aim of this research was to assess the effects of oral administration of untreated refinery effluent on the ovaries of the Norwegian rat (Rattus novergicus) and evaluate the possible ameliorating effect of the toxicity using coconut oil as abatement.

\subsection{Materials and Methods}

\subsection{Refinery effluent collection and stocking}

Refinery Effluent (Untreated wastewater or produce water including both the tank farm drainage water and the spent caustic \& MEA (Monoethanolamine)) was collected from a crude oil refinery located in Ekpan, Delta State, Nigeria. This was then transferred to the laboratory in pre-cleaned 1.5liter plastic containers and stored at room temperature until use. This was considered as the stock effluent (100\%).

\subsection{Preparation and Phytochemical analysis of Coconut Oil}

Fresh coconut (Cocos nucifera) was obtained from New Benin Market, Benin City, Edo State, Nigeria. The fresh coconut meat was grated and pressed using a sterilized sieve to produce coconut milk, which was allowed to ferment for $48 \mathrm{~h}$, after which the solids and water content were separated from the oil. The oil was then heated in a water bath slightly to remove retained moisture. The oil was filtered by passing it through a $25 \mathrm{~m}$ pore size filter (Millipore, St. Quentin, France) to give an aqueous extract of coconut oil. This was collected in a sterile vial and stored at $4{ }^{\circ} \mathrm{C}$ until use (Ogbolu et al., 2007). Phytochemical analysis was carried out and tests were conducted to determine the presence of flavonoids, tannins, cardiac glycosides, saponin, steroids, terpenoids, alkaloids, and reducing sugar according to standard methods (Harborne, 1973).

\subsection{Animal handling and experimental design}

2.3.1. Experimental animals

Thirty (30) adult female Norwegian rats weighing between 20 to $30 \mathrm{~g}$ were used for the study.

\subsubsection{Animal care and handling}

The rats were fed on growers' mash obtained from Top-Feeds, Sapele, Delta State, Nigeria and were given clean drinking water ad libitum. The animals were kept in plastic cages, under a controlled condition of $12 \mathrm{hr}$ light and $12 \mathrm{hr}$ dark cycle. The animals were maintained in accordance with the guidelines approved by the Animal Ethical Committee, University of Benin, Benin City.

\subsubsection{Animal grouping and treatment administration}

The thirty (30) animals were grouped into three $(n=10 /$ grp). Rats in group 1 were given feed with drinking water ad-libitum all through the experiment. These served as the control group. Group 2 rats were given feed with drinking water ad-libitum and also received $2 \mathrm{ml}$ of $100 \%$ of the untreated refinery effluent continuously for 9 weeks. These served as the treatment group. Group 3 rats were given feed with drinking water ad-libitum, $2 \mathrm{ml}$ of $100 \%$ of the untreated refinery effluent, and $2 \mathrm{ml}$ of Coconut oil as abatement continuously for 9 weeks. Group 3 was the abatement group. At 3 weeks intervals, two rats were sacrificed from each group and ovaries were harvested. Morphometric and histologic analyses were carried out on them. Treatment was discontinued and the remaining rats in groups 2 and 3 were designated groups 4 and 5. They were left untreated for a period of 21 days without oral administration of both the untreated refinery effluent and coconut oil for the respective groups. They were given feed and drinking water ad-libitum. This was the post-exposure stage of the experiment. At the end of the 21 days, samples from groups (4 and 5) were collected and analyzed.

\subsubsection{Physical observations, body, and organ weight determination}

Rats in each of the treatment groups were observed twice daily (before and after exposure) for signs of clinical toxicity in the appearances of the skin and fur, eyes and mucous membrane, behavioral pattern, respiratory system, morbidity and mortality. The body weight of each animal in the control and treatment groups was measured at the beginning of the experiment and at the end of exposure period using OHAUS ${ }^{\circledR}$ Scout ${ }^{\mathrm{TM}}$ Pro, Model: SPU202 digital weighing balance. 
2.3.5. Collection of specimen and analysis from experimental animals

At a three weekly interval, two (2) animals from each group were euthanized under chloroform anaesthesia. The ovaries of the animals were surgically removed and weighed, then fixed in Boiuns' fluid. The absolute organ weight was determined.

\subsubsection{Tissue concentration of heavy metals in ovaries}

The concentrations of heavy metals specifically lead $(\mathrm{Pb})$ and chromium $(\mathrm{Cr})$, in the ovaries were also determined by atomic absorption spectrophotometry as described by Brzoska et al. (2002) and Zhong et al. (2016). The model used was the Buck Scientific 210 VGP.

\subsection{Histopathology}

2.4.1. Histological preparation and examination of harvested ovaries

Ovaries harvested from the rats during the experiment were prepared for histological examination carried out at the Pathology Department, University of Benin Teaching Hospital. The organs were fixed in Bouin's fluid to arrest metabolic activities in the tissues, avoid autolysis and protein precipitation thus preventing enzymatic digestion of dead tissues. The fixed tissues were passed through several concentrations of alcohol, $70 \%$ alcohol for 24 hours and $90 \%$ alcohol for 12 hours and through absolute alcohol. This was done to remove water from the fixed tissues and allow complete infiltration of tissue by paraffin. The tissues were then passed through xylene for 3 hours to prevent shrinkage and tissue brittleness in paraffin. Blocks of paraffin were melted and placed in beakers in the oven with a temperature of $60^{\circ} \mathrm{C}$. After melting, the tissues were placed in paraffin wax. Forceps were used to arrange the tissues in the desired plane after which the wax was allowed to cool for $1 \mathrm{hr}$ $30 \mathrm{~min}$ in a water bath. Blocks of wax were attached to the block holder of the microtome which trimmed it using a planoconcave knife with the microtome gauge set at $5 \mathrm{um}$. Upon exposure of the whole tissue surface, sections were placed one at a time on a slide and flooded with egg albumin. Sections were exposed to 90 and $70 \%$ absolute alcohol for 2 minutes respectively and then in distilled water. Slides were then stained with hematoxylin for 15 minutes at room temperature and the excess stains washed in absolute alcohol. Differentiation was done using $1 \%$ acid alcohol and counter-stained with eosin for 3 minutes. Stained sections were cleared with xylene. Canada balsam was carefully placed on the stained section of the slide and a coverslip was carefully placed over the tissue to prevent air bubbles from being trapped in the slide. Slides were viewed under an Olympus Microscope (light microscope) (Nikon Eclipse E400). All alterations from the normal structure were registered. Photomicrographs were obtained at different magnifications to show the differences in tissues for the rats from each experimental group and phase.

\subsubsection{Statistical analysis}

All data were analyzed using the Statistical software, SigmaPlot for advanced statistics (Systat Inc. USA, 2010), Version 12.0. A significant difference between treatment(s) and control was analyzed with Two-Way and One-way ANOVA (Analysis of Variance) under DMR test (Duncan Multiple Ratio) for pair-wise comparison to detect significant differences at $P \leq 0.05$.

\subsection{Phytochemical analysis of coconut oil}

Coconut oil was found to be rich in essential constituents that could serve as anti-oxidants and also useful in nutrient enrichment. This included flavonoids, terpenoids, steroids, anthraquinones, saponin, reducing sugar, alkaloids, tannins and cardiac glycosides.

\subsection{Physical observation and behavioural changes}

During the duration of exposure of rats to effluents, increased water intake was observed in rats across the treatment groups compared to control (per observation). After 2 weeks of exposure, there was a continued increase in body sizes across all group (Figure 1). At the end of the sixth week, rats in the group given effluent only and also those given coconut oil as abatement were more active. Other observations which can be termed as clinical symptoms such as diarrhea, loss of fur, regional edema and loss of appetite were also observed in refinery effluent treated rats. 


\subsection{Results}

\subsection{Body weight}

There was a significant difference $(P<0.05)$ in body weight of rats at 3,6 and 9 weeks of treatment (Table 1). Body weight of rats increased across all treatment groups (Figure 1). Rats treated with effluent and coconut oil as abatement showed an increase in body weight from week 10 to 11 with body weight decreasing from week 11 to 12 and an increase in body weight observed from 12-13 weeks (Figure 1).

Table 1: Results of repeated measures ANOVA and test of significance of mean body weights between various time points across control, effluent and coconut oil abated groups.

\begin{tabular}{|c|c|c|c|c|c|c|c|c|}
\hline \multirow[t]{2}{*}{ Weight } & \multirow{2}{*}{$\begin{array}{l}\text { Time period } \\
\text { (weeks) }\end{array}$} & \multirow{2}{*}{$\begin{array}{l}\text { Time } \\
\text { point }\end{array}$} & \multirow{2}{*}{$\begin{array}{l}\text { Body weight (g) } \\
\text { Mean } \pm \text { SE }\end{array}$} & \multicolumn{2}{|c|}{$95 \% \mathrm{CI}$} & \multirow{2}{*}{$\begin{array}{l}\text { Compared } \\
\text { time points }\end{array}$} & \multirow{2}{*}{$\begin{array}{l}\text { Mean } \\
\text { difference }\end{array}$} & \multirow[t]{2}{*}{$P$} \\
\hline & & & & From & To & & & \\
\hline \multirow[t]{22}{*}{ Body } & 3 & 0 & $107.1 \pm 6.26$ & 92.281 & 121.886 & $0-1$ & -36.250 & $<0.0001$ \\
\hline & & 1 & $143.3 \pm 6.03$ & 129.085 & 157.582 & $0-2$ & -46.25 & $<0.0001$ \\
\hline & & 2 & $153.3 \pm 7.91$ & 134.639 & 172.027 & $0-3$ & -61.25 & $<0.0001$ \\
\hline & & 3 & $168.3 \pm 10.47$ & 143.587 & 193.08 & $1-2$ & -10.0 & 0.032 \\
\hline & & & & & & $1-3$ & -25.0 & 0.007 \\
\hline & & & & & & $2-3$ & -15.0 & 0.016 \\
\hline & 6 & 0 & $101.7 \pm 9.70$ & 74.729 & 128.605 & $0-4$ & $\begin{array}{l}-68.889 \\
\end{array}$ & 0.004 \\
\hline & & 4 & $170.6 \pm 15.54$ & 127.408 & 213.703 & $0-5$ & -73.333 & 0.001 \\
\hline & & 5 & $175.0 \pm 11.55$ & 142.922 & 207.078 & $0-6$ & -81.667 & 0.001 \\
\hline & & 6 & $183.3 \pm 9.62$ & 156.617 & 210.05 & $4-5$ & -4.444 & $>0.05$ \\
\hline & & & & & & $4-6$ & -12.778 & $>0.05$ \\
\hline & & & & & & $5-6$ & -8.333 & $>0.05$ \\
\hline & 9 & 0 & $102.5 \pm 7.30$ & 71.139 & 133.861 & $0-7$ & -85 & 0.023 \\
\hline & & 7 & $187.5 \pm 10.0$ & 144.473 & 230.527 & $0-8$ & -91.25 & 0.041 \\
\hline & & 8 & $193.8 \pm 14.63$ & 130.798 & 256.702 & $0-9$ & -88.75 & 0.094 \\
\hline & & 9 & $191.3 \pm 9.76$ & 149.244 & 233.256 & $7-8$ & -6.25 & $>0.05$ \\
\hline & & & & & & $7-9$ & -3.75 & $>0.05$ \\
\hline & & & & & & $8-9$ & 3.75 & $>0.05$ \\
\hline & 13 & 10 & 182.5 & & & & & \\
\hline & & 11 & 195 & & & & & \\
\hline & & 12 & 187.5 & & & & & \\
\hline & & 13 & 190 & & & & & \\
\hline
\end{tabular}

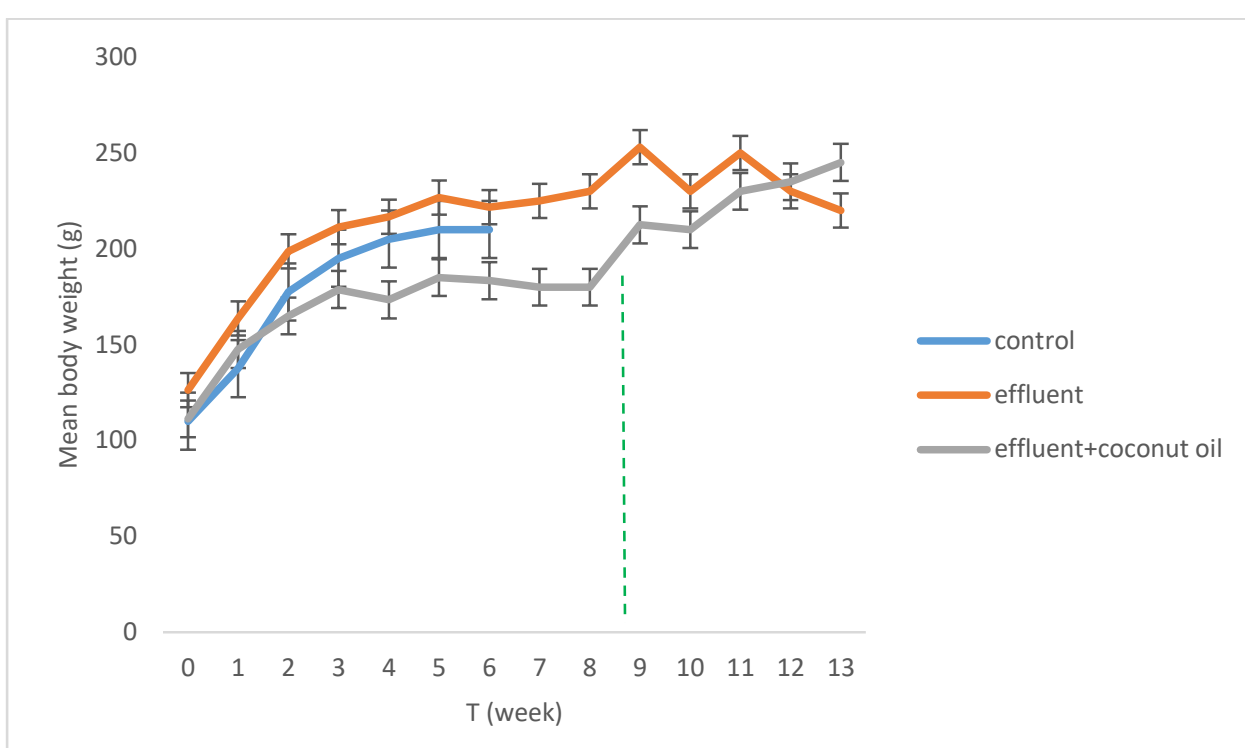

Figure 1: Changes in mean in mean body weight across experimental and control groups respectively during and after amelioration with coconut oil.

\subsection{Tissue concentration of heavy metals chromium $(\mathrm{Cr})$ and lead $(\mathrm{Pb})$}

Ovaries were found to contain certain detectable concentrations of chromium $(\mathrm{Cr})$ and lead $(\mathrm{Pb})(\mathrm{see}$ Figure 2). 


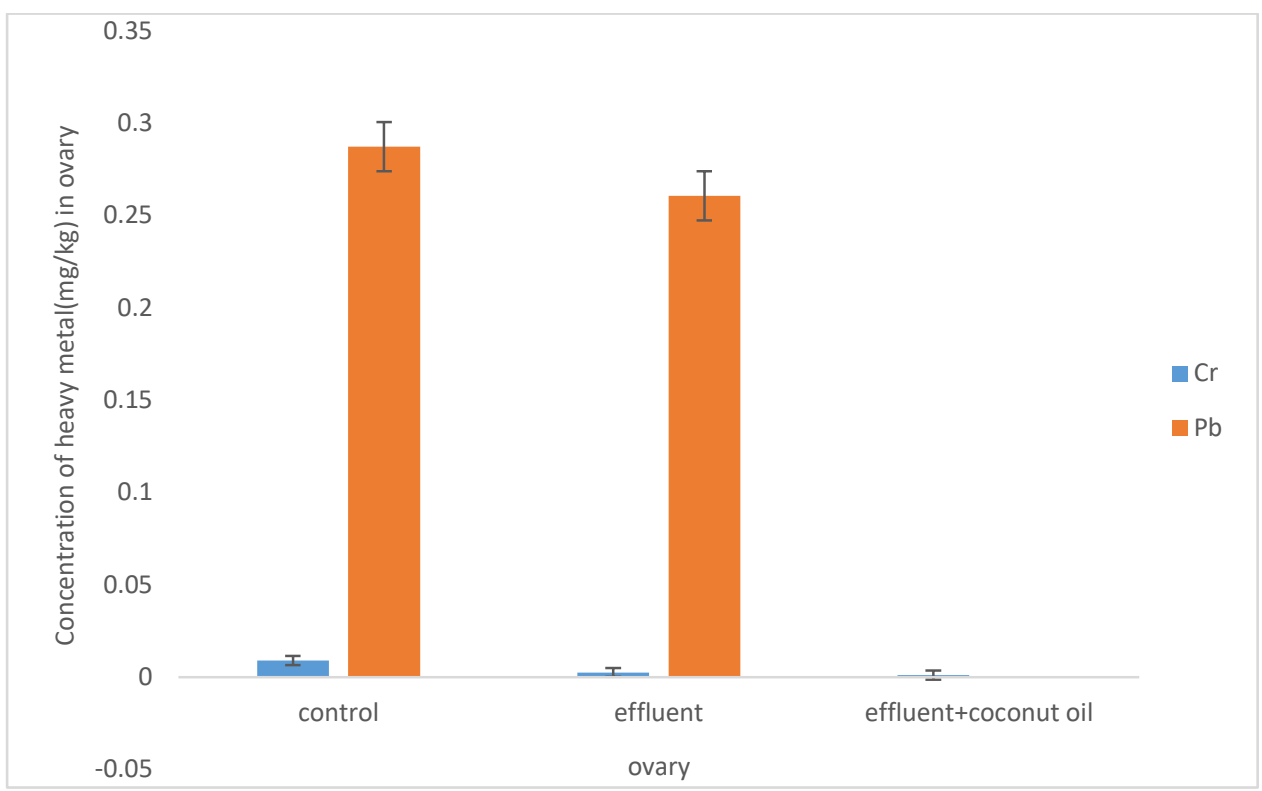

Figure 2: Mean concentration of chromium $(\mathrm{Cr})$ and lead $(\mathrm{Pb})$ respectively in the ovary across experimental and control groups.

\subsection{Histopathology}

The results of the histologic examination of ovaries of Norwegian rats are presented at 9 weeks of exposure; ovaries of the control group showed normal matured and developing ovarian follicles at different levels of maturation with normal granulosa cells, the basal lamina and the antrial fluid (Figure 3A), the granulosa cells were severely sloughed off in the effluent treated (Figure 3B) while the coconut oil abated group had moderate sloughing off of the granulosa cells with the basal lamina intact (Figure 3C).
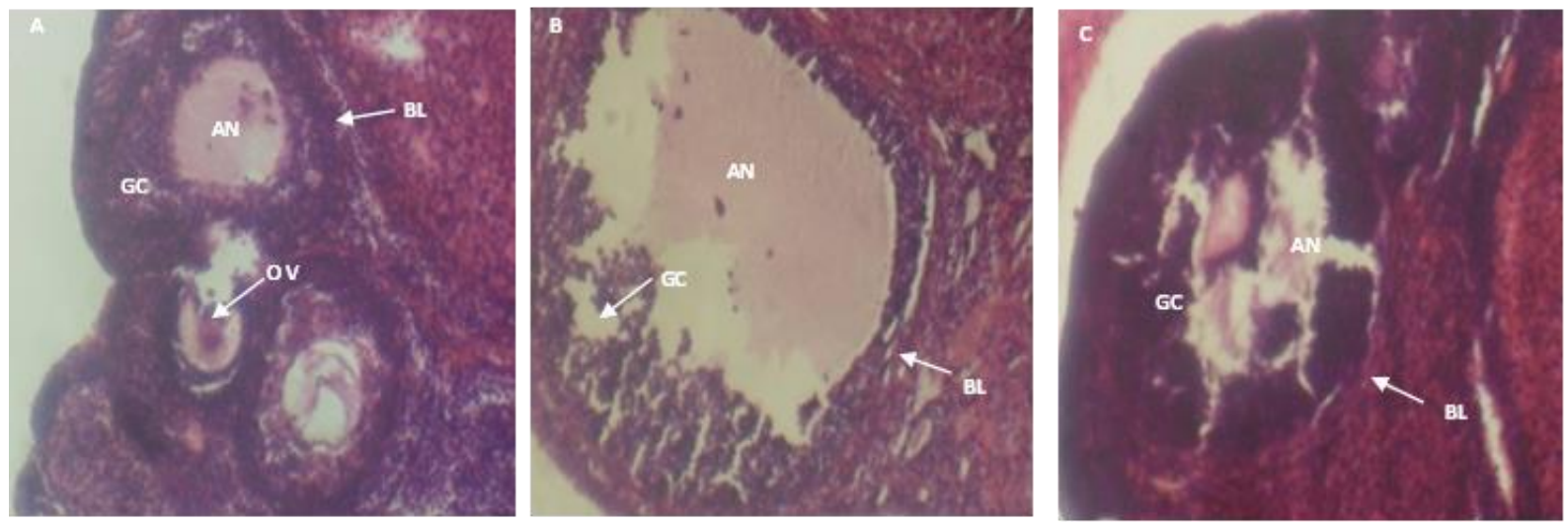

Figure 3: Photomicrograph of Norwegian rats mature ovaries, showing in $\mathbf{A}$, the control group, ovulatory follicle (OV). Note the integrity of the granulosa cells (GC) and the basal lamina (BL), and the antrial fluid (AN). In $\mathbf{B}$, the granulosa cells are sloughed off as seen in $\mathbf{C}$, although the basal lamina are apparently intact.

\subsection{Antimicrobial activities of coconut oil}

All bacterial isolates were inhibited at concentration of $100 \mathrm{mg} / \mathrm{ml}$ in coconut oil with Micrococcus spp having the highest zone of inhibition $(19 \mathrm{~mm}, 14 \mathrm{~mm})$ and Klebsiella spp having the lowest $(4 \mathrm{~mm})$ for coconut oil.

\subsection{Discussion}

Results showed that lead $(\mathrm{Pb})$ had a higher concentration in the ovary as compared to chromium $(\mathrm{Cr})$ in both intoxicated and intoxicated/ameliorated groups. While lead concentration was $0.27 \mathrm{mg} / \mathrm{kg}$ in the intoxicated group, it was $0.25 \mathrm{mg} / \mathrm{kg}$ in coconut oil treated group and chromium was $0.02 \mathrm{mg}$ and $0.01 \mathrm{mg}$ in the intoxicated and coconut oil treated group respectively. 
At 3 and 6 weeks the majority of the treated rats showed ovarian atrophy. At nine weeks the coconut oil abated group showed matured follicles which are suggestive of active ovarian activity due to the ameliorative effect of coconut oil. Increase in ovary weight has been reported in chinchilla rabbits exposed to Escravos crude oil. This was attributed to enlargement of follicles in the ovary which is probably induced by the crude oil. However, the ovary weight and morphology were not estimated in this study because the ovary of some of the rats was atrophied. However, significant weight changes in the ovary of rats exposed to Lead during pregnancy was not observed by an earlier study (Okoye et al., 2014). A 40\% reduction in fertility rate had earlier been reported for rats fed with $60 \mathrm{mg} / \mathrm{kg}$ of Lead (Wiebe et al., 1988). The decrease in fertility was attributed to a possible decrease in acetylcholine concentration which is important for steroidogenesis. Also, an irregular estrus cycling in female albino rats exposed to lead has been reported (Der et al., 1985; Dhir and Dhand, 2010).

In this study, rats in the refinery effluent intoxicated groups showed a level of degenerated follicular architecture with follicles not having ovum (enucleated) with varying degrees of atrophy. This agreed with previous reports (Ronis et al., 1998). Others had disorganized granulosa cells and stromal inflammation. However, rats in the coconut oil abated group showed follicles in the different stages of development (maturation), showing recovery from the damaged state. This research has shown that the biologically active ingredients which are found in coconut oil have an ameliorative effect on the ovaries of rats exposed to lead and chromium and initiated early regeneration and return to function of the ovarian follicles after intoxication with refinery effluents.

Ovarian sections from group 2 revealed severe congestion and degeneration of follicles. In addition, cystic follicles were seen in large numbers. Ultrastructural changes like alterations in size and shape of basal laminal and granulosa cells were also noticed in group 2 rats. Recovery from histological injury had been observed in $\alpha$-tocopherol co-administered rats, with mild cloudy swelling in uterus and congestion in ovaries (Ronis et al., 1998). In this study, ultra-structurally, no changes were noticed in group 3 rats. Potassium dichromate treatment causes a significant negative change $(P<$ 0.05 ) in uterine and ovarian weights, serum GSH level, percentage of vaginal time opening and diameter of ovarian follicles in categories (101-200) and (> 400), with a significant increase in serum MDA level (Balakrishnan et al., 2013).

Banu et al., (2008) stated that many environmental toxicants gain access to the ovary via the circulation. The risk of damage to the ovarian follicle cell population from the toxicants depends mainly on the accessibility of toxicants to ovarian follicles. Recent studies found out that there was a decrease in ovarian weight and lipid peroxidation of female mice treated with chromium trichloride, these findings are similar to this study (Elbetieha and Al-hamood, 1997; Banu et al., 2008; Jeber and Tawfeek, 2013). Banu et al., (2008) also found a decrease in the percentage of vaginal opening time in female rats treated with potassium dichromate as an index of delay onset of puberty in female rats and decreased in a number of primordial, primary and secondary follicles with no observation of antrial follicles. This was also reported in earlier studies (Dosumu et al., 2010; Adikwu et al., 2013).

Rats in the intoxicated and abated groups had varying degrees of degeneration of the atrophied ovaries within 3 to 6 weeks of treatment. After 9 weeks of exposure, those in the ameliorated group showed levels of regeneration in the ovarian follicular architecture; with follicles tending to varying levels of maturation and showing recovery from the damaged state. After the 21 days, post-exposure period matured ovarian follicles were seen in the coconut oil ameliorated group.

\subsection{Conclusion}

The study concluded that intoxication from refinery effluents resulted in a high accumulation of heavy metals chromium $(\mathrm{Cr})$ and lead $(\mathrm{Pb})$ in the ovaries of exposed rats. There was ovarian atrophy in Norwegian rats intoxicated with refinery effluents. High deposits of Lead and Chromium could be a leading cause of follicular degeneration in the ovaries of Norwegian rats intoxicated with refinery effluents. Effluents from the refinery and other chemical industries containing heavy metals should be treated and disposed of properly to reduce the level of environmental pollution. Finally, coconut oil ameliorated the toxic effects of refinery effluent in the ovaries of Norwegian rats. 


\section{References}

Adikwu, E., Oputiri, D., Oru-Bo, P.G. and Enimeya. D.A. (2013). Lead organ and tissue toxicity: Roles of mitigating agents (Part 1). British Journal of Pharmacology and Toxicology, 4(6), pp. 232 240 .

Balakrishnan, R., Satish-Kumar, C.S.V., Usha-Rani, M., Kavita, K., Boobalan, G. and Gopala-Reddy, A. (2013). Evaluation of protective action of $\alpha$-tocopherol in chromium Induced oxidative stress in female reproductive system of rats. Journal of Natural Science Biology and Medicine, 4(1), pp. 87-93.

Banu, S.K., Samuel, J.B., Arosh, J.A., Burghardt. R.C. and Aruldhas, M.M. (2008). Lactational exposure to hexavalent chromium delays puberty by impairing ovarian development, steroidogenesis and pituitary hormone synthesis in developing Wister rats. Toxicology and Applied Pharmacology, 232, pp.180-189.

Brzoska, M.M., Moniuszko, J., Rzoska, J., Moniuszko-Jakoniuk, M., Jurczuk, M. and Ga-LaoynSidorczuk, G.A. (2002). Cadmiun turnover and changes of zinc and copper body status of rats continuously exposed to cadmium and ethanol. Alcohol and Alcoholism, 37(3), pp. 213-221.

Calvero, F., Campani, S., Ragghianti, M., Bucci, S. and Mancino, G. (1998). Tests of toxicity and teratogenicity in biphasic vertebrates treated with heavy metals (cr3+, al3+, cd2+). Chemosphere, 37(14-15), pp. 3011-3017.

Campbell, W.W., Polansky, M.M., Bryden, N.A., Soares, J.H. and Anderson, R.A. (1989). Exercise training and dietary chromium effects on glycogen, glycogen synthase, phosphorylase and total protein in rats. Journal of Nutrition, 119(4), pp. 653-660.

Der, R., Fahim, Z., Hilderbrand, D. and Fahim, M. (1985). Combined Effect of Lead and Less Protein on Growth, Sexual Development and Metabolism in Female Rats. Research Communications in Chemical Pathology and Pharmacology, 9, pp.723-738.

Dhir, V. and Dhand, P. (2010). Toxicological Approach in Chronic Exposure to Lead on Reproductive Functions in Female Rats. Toxicology International, 17 (1), pp. 1-7.

Dosumu, O.O., Duru, F.I.O., Osinubi, A.A., Oremosu, A.A. and Noronha, C.C. (2010). Influence of virgin coconut oil (VCNO) on oxidative stress, serum testosterone and gonadotropic hormones (FSH, LH) in chronic ethanol ingestion. Agricultural Biology Journal of North America, 6, pp. 1126-1132.

Elbetieha, A. and Al-Hamood, M.H. (1997). Long term exposure effect on fertility of male and female mice to trivalent and hexavalent chromium compounds. Toxicology, 116, pp. 39-47.

Enig, M. (2000). Know Your Fats- The Complete Primer for Understanding the Nutrition of Fats, Oils and Cholesterol. Bethesda Press; Silver Spring, Maryland, USA, pp. 124.

Giridharan, N.V. (2000) Indian Council of Medical Research: Use of Animals in Scientific Research 2000. Retrieved May 282013 (http://icmr.nic.in/bioethics/Animals_biomedicalresearch.pdf).

Harborne, J.B. (1973). Phytochemical Methods. Chapman and Hall Ltd., London, pp. 49-188.

Ihedioha, J.I., Okafor, C. and Ihedioha, T.E. (2004). The haematological profile of the SpragueDawley outbred albino rat in Nsukka, Nigeria. Animal Research International, 1, pp. 125-132.

Isaacs, C.E., Litov, R.E. and Thormar, H. (1995). Antimicrobial activity of lipids added to human milk, infant formula and bovine milk. Journal of Nutritional Biochemistry, 6, pp. 362-366.

Isselhard, W.H. and Kushe, J. (1998). Animal experimentation. In. Troidl, H., M. F. McKneally, D. S. Mulder, W. O. Spitzer, B. McPeek (eds) Principles and practice of research: Strategies for surgical investigators 3rd Edition. New York: Springer-Verlag. Pp. 419-434. 
Jeber, Z.K. and Tawfeek, F.K. (2012). Effects of turmeric oil in reproductive efficiency of immature female rats exposed to oxidative stress induced by potassium dichromate. IOSR Journal of Pharmacy and Biological Sciences, 4(4), pp. 9-13.

Kanojia, R.K., Junaid, M. and Murthy, R.C. (1998). Embryo and fetotoxicity of hexavalent chromium: A long-term study. Toxicology Letters, 95, pp. 165-172.

Ogbolu, D.O., Oni, A.A, Daini, O.A. and Oloko, A.P. (2007). In vitro antimicrobial properties of Coconut oil on Candida species in Ibadan, Nigeria. Journal of Medicinal Food, 10(2), pp. 384 -387.

Okoye, J.O., Ngokere, A.A., Ogenyi, S.I. and Onyemelukwe, A.O. (2014). Histopathological and hormonal disrupting effects of Escravos crude oil on the ovary of Chinchilla rabbits. Journal of Toxicology and Environmental Health Sciences, 6(2), pp. 31 -37.

Ronis, M.J., Badger, T.M., Shema, S.J., Robertson, P.K. and Shaik F. 1998). Effectss on Pubertal Growth and reproduction in Rats Exposed to Lead Perinatally or Continuosuly Throughtout Development. Journal of Toxicology and Environmental Health, 13, pp. 327-41.

Tawari - Fufeyin, P., Oronsaye. J.A.O. and Ajufoh, V.U. (2002). Preliminary studies on the tissues of the upper alimentary canal of the Norway rat (Rattus norvegieus) fed with cadmium salt. Discovery and Innovation, 14(3/4), pp. 34- 43.

Thormar, P.K. (1996). Handbook on Coconut Palm; Oxford \& IBH Publishing Co. New Delhi, India.

Wiebe, J.P., Barr, K.J. and Buckingham. K.D. (1988). Effect of Prenatal and Neonatal Exposure to Lead on Gonadotropin Receptors on Steriodogenesis in Rats Ovaries. Journal of Toxicology and Environmental Health, 24, pp. 461-76.

Zhong, W., Ren, T. and Zhao, L. (2016). Determination of Pb (Lead), Cd (Cadmium), Cr (Chromium), $\mathrm{Cu}$ (Copper), and $\mathrm{Ni}$ (Nickel) in Chinese tea with high-resolution continuum source graphite furnace atomic absorption spectrometry, Journal of Food and Drug Analysis, 24, pp. 46 - 55. 